INTERDISCIPLINARIA ARCHAEOLOGICA NATURAL SCIENCES IN ARCHAEOLOGY

\title{
Old World Methods, New World Pots. The Introduction of the Potter's Wheel to the Spanish Colonies of Concepción de la Vega and Cotuí (Dominican Republic 1495-1562)
}

\author{
Marlieke Ernst $\mathrm{t}^{1,2^{*}}$ \\ ${ }^{1}$ Leiden University, Einsteinweg 2, 2333 CC Leiden, the Netherlands \\ ${ }^{2}$ KITLV - Royal Institute of Southeast Asian and Caribbean Studies, Reuvensplaats 2, 2311 BE Leiden, the Netherlands
}

\section{ARTICLE INFO}

\section{Article history:}

Received: $1^{\text {st }}$ February 2021

Accepted: 23 ${ }^{\text {rd }}$ August 2021

DOI: http://dx.doi.org/10.24916/iansa.2021.2.10

\section{Key words:}

chaîne opératoire

wheel-coiling

ceramic technology

colonialism

transculturation

intercultural interaction

\begin{abstract}
A B S TR ACT
Wheel-made ceramics from early colonial Caribbean sites (1492-1562) have traditionally been labelled as European imports. This paper challenges that assumption, as the intercultural interactions within colonies in the New World have led to the creation of new social identities and changing material culture repertoires. Macro-trace ceramic analysis from the sites of Concepción de la Vega and Cotuí (Hispaniola, present-day Dominican Republic) show that the potter's wheel was in fact introduced to the Spanish colonies at an early stage. The evidence of RKE (rotative kinetic energy) on sherds and the discovery of parts of a potter's wheel are the earliest traces of the potter's wheel found in the Americas. Here we aim to present how the potter's wheel was introduced within the context of transcultural pottery forming. This paper will show that traditional coiling techniques were supplemented with finishing techniques on the wheel. The transformation processes within ceramic repertoires are assessed through theories of colonialism and learning processes, combined with archaeological and ethnoarchaeological assessment of the ceramic chaîne opératoire. Evidence from ceramic analysis is combined with historical sources to understand social processes surrounding the technological changes behind the introduction of the potter's wheel to the New World colonies.
\end{abstract}

\section{Introduction}

The early colonial Spanish Caribbean, from the arrival of Columbus in 1492 until 1562, was a space in which many cultures were forced to interact through the process of colonization (Hofman and Keehnen, 2019; Ulloa Hung et al., 2021). The island of Hispaniola (present-day Haiti and the Dominican Republic) was the first island to experience largescale intercultural interactions as a result of Spanish colonial actions. This set the stage for the course of colonization in the rest of the Americas (Hofman et al., 2018; forthcoming). Results of the first encounters between the Spanish colonizers and the inhabitants of the island encompassed (armed) conflicts, invasion, conquest, enslavement, misunderstandings, and a range of other intercultural interactions including intermarriage, as well as exchange of goods, food items, and ideas (Deagan, 1988; 2004; Hofman et al., forthcoming; Sauer,

*Corresponding author. E-mail: marlieke_ernst@hotmail.com
1966; Valcárcel Rojas et al., 2013; 2019). These exchanges resulted in a process of transculturation; a creative, ongoing process of appropriation, imitation, revision, negotiation, and survival in both social and material dimensions (Ortiz, [1940] 1955). Here transculturation is seen as the (re)negotiation of cultural values and the creation of new materials as a result. Most researchers recognise this process occurring within a somewhat equal colonial situation (Middle-Ground colonialism, Gosden, 2006). However, the agency of colonised and enslaved individuals within a Terra Nullius situation (a more drastic colonial category such as the case in the Spanish Americas), should not be discarded. Scholars have come to understand that subjugated people are not simply victims of their particular colonial histories, but rather that they are active players in the creation of social, political and ideological aspects of social life (Spielman et al., 2006). Here I consider that their (subaltern) agency is therefore also reflected within the material culture manufactured and used during the lives of the people of the early colonial Caribbean. 


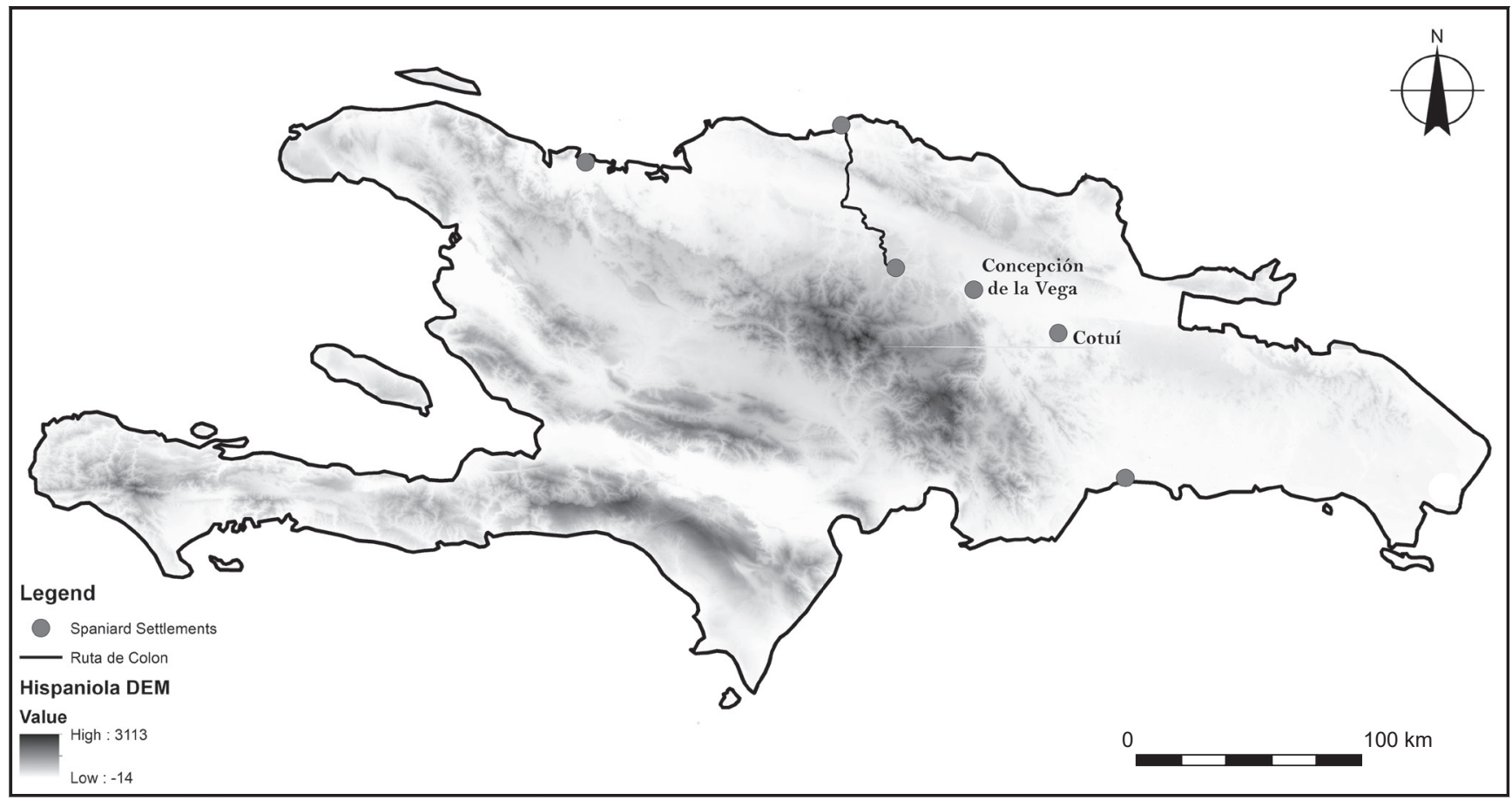

Figure 1. Map of the island of Hispaniola with the locations of Concepción de la Vega and Cotuí by Marlieke Ernst.

Interaction, negotiation, and transculturation did not solely occur between the Indigenous peoples of Hispaniola and the colonists from Spain: there were multiple cultures at play. In 1503, the Spanish Crown granted legal justification to forcibly remove, relocate, and enslave Indigenous peoples across the islands (Anderson-Córdova, 2017; Hofman et al., 2018; Rivera-Pagán, 2003; Sued Badillo, 2001; Ulloa Hung et al., 2021). As a result, Hispaniola saw an influx of Indigenous enslaved labourers from surrounding islands and the mainland of South America. By 1505, the Crown authorised the relocation of African enslaved peoples to the islands. This was initially for the African enslaved peoples already enslaved in Europe, but later this relocation was also legally justified for forceful removal of enslaved peoples directly from Africa (Deive, 1980; Palmié, 2011; RiveraPagán, 2003). These processes resulted in the formation of communities of enslaved Indigenous and African peoples within Spanish colonial cities, creating a very diverse, multicultural, colonial society.

This paper assesses intercultural interactions and the transculturation process within the wheel-made ceramics excavated from two coexisting colonial sites in Hispaniola the fort of Concepción de la Vega and one of its surrounding goldmines, Cotuí - to show how techniques and styles from different cultural backgrounds merged to a new ceramic repertoire reflecting the colonial realities. Material culture from early colonial sites can offer key insights into various interactions between people living within the colonial realities (Deagan, 1988; 1998; 2004; Deagan and Cruxent, 2002; Hofman et al., forthcoming). Within early colonial Caribbean archaeology, the material culture of the colonies has (up until recently) been studied from a historical bias in which Indigenous peoples of the Caribbean disappeared within a couple of decades after the conquest, with no room for much subaltern agency (Deagan and Cruxent, 2002; Rouse, 1992; Ulloa Hung et al., 2021; Wilson, 1990). This was also the case for the ceramics presented here. The sherds of this ceramics have very clear traces that evidence the use of the potter's wheel and because of this historical bias have thus been labelled as prior European imports (Deagan, 1999; Ortega and Fondeur, 1987b). I would like to challenge that assumption, as the intercultural encounters within colonies in the New World led to the creation of new social identities and changing material culture repertoires. Macro-trace ceramic analysis of the chaînes opératoires present within these ceramics show that the potter's wheel was introduced to the Spanish colonies at an early stage, offering new venues for studying transculturation within the creation of ceramics. In this article I will first briefly discuss the historical background of the sites studied in order to better understand the cultures present within the colonies. Then I will go into the ways we can study ceramic change and the methodologies applied in this study; then the ceramic data will be presented. In the discussion, interpretations will be made about the manufacturing techniques, morphologies, and styles in connection to the historical background of the colonial towns.

\section{The Spanish colonies Concepción de la Vega and Cotuí}

The colonial town of Concepción de la Vega (Figure 1), consisting of a military fort, a monastery, and a residential 
part of the town, existed between 1494 and 1562. La Vega was the largest Spanish settlement on the island during the early colonial period, and housed both elite and nonelite European colonists, as well as Indigenous and African enslaved peoples. This variety of peoples present in the city makes this city a perfect case study for assessing colonial intercultural interactions and transculturation. Situated in the Cibao Valley, the town played an important role for the Spaniards in gaining gold. Its economy was mainly based on gold mining by the enslaved Indigenous and African workers (with gold mines surrounding the city) and gold minting (Guerro, 2005; Las Casas, 1974, vol. 2). It soon became a commercial and cosmopolitan place in which many people were forcefully put to work as well as living within their colonial realities (Cohen, 1997). Later, a shift towards sugar production and cattle herding occurred (Cohen, 1997; Deagan, 1999; Kulstad, 2019; Shephard, 1997). Concepción de la Vega was excavated in the 1950s by John Goggin, in 1976-1979 by José González, and in 1994 by the University of Florida. The archaeological materials found at the site reflect the many cultures living in Concepción de la Vega, as they consist of a mix of Spanish and Indigenous artifacts (García Arévalos, 1978; Kulstad, 2019), as well as some transcultural artifacts showcasing Indigenous, Spanish, and African technologies and styles (see Ernst, in prep.). The great abundance of material culture indicates the wealth of the colony (García Arévalo, 1978; Kulstad, 2019). Interesting for this research is the archaeological find of a tournette, a part of the potters' wheel, suggesting on site pot-making (Card, 2007; Ortega, 1980, p.271).

Cotuí ( or site 11, Figure 1) is also known as the colonial mining camp of the first goldmine exploited by the Europeans in the New World and dates between 1505 and 1562 (Olsen Bogaert et al., 2011a; Rincón, 2004). The gold of Cotuí was minted twice a year in Concepción de la Vega. The camp comprised of a church and the mining camp, which consisted of three plots of stone buildings. Additionally, 8 postholes were found, which possibly represent a perishable booth or a place to prepare food or to process the mined materials (Olsen Bogeart etal., 2011a; 2011b). The material assemblage from the 2007-2008 excavations of this mining camp included Spanish, Indigenous and transcultural materials and most of the artefacts were ceramics. Various stone tools were recovered, including tools likely used in the manufacture of ceramics, indicating on-site pottery production (Olsen Bogeart, 2011a). The presence of luxury metal and glass objects reflect the importance of the mine to the colonists (Olsen Bogeart et al., 2011a; 2011b)

\section{Ceramic analysis towards ceramic change}

In order to understand transculturation within early colonial ceramics, this research will study continuity and changes in the ceramic chaînes opératoires from Concepción de la Vega and Cotuí. By studying what traditions were kept and what changed, scholars can gain insight into what was important to the manufacturer and/or consumer. Consumers, in this case, can be both enslaved peoples as well as colonizers. Both have to be taken into account when interpreting the ceramic data, were it to do with different theories with regard to colonial power-relations or otherwise. When it comes to influences on the transculturation process we can hypothesise cases of subaltern agency and resistance against the colonial regime (certain traditions are continued as they are of importance to the colonised) (Bogues, 2002; Cooper, 1994; Edwards, 2017; Guha, 1982; Hintzen, 2005; James, 1963), cultural negotiation (the re-evaluation of traditions and the incorporation of new ones) (Ortiz, [1940] 1955), but also the colonial demand of maintaining parts of the life they had left behind (the re-creation of Spanish life in the New World) (Deagan and Cruxent, 2002b; McEwan, 1995; Ortega, 1980).

Here the continuity and changes in ceramic production are investigated through both a technological approach by studying the macro-traces, as well as a morphological and stylistic study of the ceramics. Interpretation of the meaning of the technique, shape, and style serve to cross-check one another, and each ceramic feature is best understood in its relation to the whole (Ernst, in prep.; Shepard, 1976). The ceramics analysed for this study come from the previous extensive excavations at Concepción de la Vega and Cotuí. The ceramics were analysed in the Dominican Republic in both the Museo del Hobre Dominicano and on site at Concepción de la Vega where most of the archaeological materials from the excavations are stored. The ceramic sherds were classified by vessel shape and wall profile, lip shape and rim profile, wall thickness, orifice diameter and percentage of rim present, decorations, vessel interior and exterior Munsell colours, firing atmosphere, surface finish, and the presence of slips or appendages (Hofman, 1993). The interpretation of ceramic manufacture techniques relies on diagnostic features that provide information on the techniques, methods, procedures, tools, and/or gestures used. This research mostly follows Valentine Roux's methodology for identifying traces of the chaînes opératoires in ceramic objects (adapted for the situation in the field where little to no electricity was present) (Ernst, in prep.; Ernst and Hofman, 2019; Manem, 2008; Roux, 2016b; 2019; Roux and Courty, 2013). This approach enables the study of the manufacture process of material culture, and reveals the technological choices made by the potter (Leroi-Gourhan, 1964; Roux, 2016a; 2016b; 2019). Similar to many Caribbean archaeological assemblages, the presented case studies yielded mostly small fragments of a variety of vessel shapes. In order to recognise features that establish a hypothetical relationship for a group of sherds, selection was carried out according the presence of macrotraces for wheel-made ceramics. Sherds that displayed traces of rilling, concentric striations of the base, and drag marks were selected during the study of the entire ceramic assemblages of Concepción de la Vega and Cotuí (Ernst, in prep.). Description of macro-traces is carried out on both the internal and external surfaces of sherds, as well as the cross sections. Macrotraces include attributes 
visible to the naked eye as well as attributes visible under low magnification (40×) (Roux, 2016b; 2019).

The chaines opératoires of ceramics reflect the potters' different technological traditions, networks, and strategies (Duistermaat, 2016; Herbich and Dietler, 2008; Gosselain, 2000; 2011; Lemonnier, 1992; 2012; Leroi-Gourhan, 1964; Roux, 2016b). The techniques applied are determined by the potters' conceptualisation of pottery technologies. These technologies involve motor skills and specialised gestures deeply rooted within the learned behaviours of the potter (Rice, 1984; Skibo and Schiffer, 2008). This pottery technology is what potters express as essential characteristics of their wares, especially in terms of how they think pots should be made and what they look like. Even within such drastic situations as colonialism, it has been shown that maintaining part of these technologies are a way to maintain ties to the potter's roots and identity. At the same time, these technological traditions are not completely static and can change as a result of a variety of internal and external factors as the potters adapt to new situations. Some of these factors include invasion and conquest, as well as innovation and inspiration through new cultural forms. People within intercultural interactions may bring their own objects and ideas to the transculturation process, which result in changes to established manufacturing techniques (Duistermaat, 2016; Gosselain, 1998; 1999; 2000; Livingstone Smith, 2000; van der Leeuw, 1993; Rice, 1984; Roux, 2016a; Wallaert, 2008). It is therefore possible to expect transculturation within the creation of ceramics in a colonial situation.

In order to understand the creation and mixing of the chaînes opératoires, morphology, and styles within the assemblages, in their colonial context, a comparison has to be made with precolonial ceramic traditions. In assessing the transculturation within the analysed ceramics, it is important to not only compare the traditions present in the La Vega and Cotuí ceramic assemblages with pre-1492 Hispaniolan traditions, but also with ceramics from historicallyknown cultures present in the studied colonies. In order to assess the precolonial (from just before or around 1492) Caribbean, European, and African ceramic technologies and styles, an extensive literature research was conducted, in combination with stylistic analysis in several museums (Ernst, in prep.). Combining the ceramic data from this study with the ceramic traditions pre-1492 and the historical data about the people living and working in Concepción de la Vega and Cotuí (Las Casas, [1527] 1974; Oviedo, [1535] 1851; Pané, [1571] 1999) offers us a unique vision on systems of colonialism as well as subaltern agencies, negotiation, and resistance.

\section{Wheel-made ceramics in the colonies}

The ceramic assemblage presented in this paper has traditionally been classified as European import wares, as the potter's wheel was not indigenous to the Caribbean pre-1492. They have been classified as wares similar to the Merida ware, whose origins are attributed to Merida in southwestern Spain. They are theorised to be a mass-produced export ware for the colonies (Deagan, 1987; Ortega, 1980; Ortega and Fondeur, 1978a; 1978b; Vicens Vives, 1969). However, pastes of these sherds closely resemble pastes from more locally-produced, indigenous ceramics on a macroscopic level, although less coarsely tempered than the indigenous sherds. Eventually, petrographic analysis of the two varieties of clays of this type (conducted by the KU Leuven) suggests a local provenance for these clays (Ernst, in prep.; Stienaers, pers. comm.; Ting et al., 2018). This, together with the find of a partial potter's wheel at la Vega (Card, 2007; Ortega and Fondeur, 1978b), suggests the introduction of wheel-made ceramics in early colonial Hispaniola.

The types presented here are based on the chaîne opératoire, morphology, and style. Unfortunately, very few complete vessels with traces of the wheel were recovered. Based on rim sherds of at least five $\mathrm{cm}$ in size, a reconstruction could be made of the vessel orifice. There are two differences within the chaînes opératoires of the wheel-made ceramics in connection to the vessel shape and the decorations, as outlined below.

\subsection{Type 1}

The first type consists of the smallest group within the wheelmade ceramics (Figure 2). Generally seen, most of the clays selected for the manufacture of these ceramics were of a very-fine to fine clay of a red to reddish-brown or greyishbrown paste. Macrotraces present in this group evidence rilling and drag marks on the inner and outer surface of the vessel as a result of the continuous pressures from the fingers or potter's tools (Jeffra, 2011; Courty and Roux, 1995; Roux and Courty, 1998). They show rhythmic ridges and grooves that spiral around the vessel's walls. They are present both on the inside and the outside of the sherds. Concentric striations on the bottom of the base are also amongst the characteristics. These are caused by the cutting off of the vessel from the turning wheel with a wire or thread, either while the wheel is rotating or stationary (Roux, 2019).

Here I consciously use the phrase 'wheel-made' instead of 'wheel-thrown'. Closer examination of the sherds that exhibit traces of the potter's wheel reveals that the potter's wheel was not used in the roughout stage of the ceramic chaîne opératoire. Instead, the initial hollow form from clay is created by coiling - and the potter's wheel is then used as a shaping technique. Coil sizes range from 1.5 to $2 \mathrm{~cm}$. The combination of coiling and wheel-shaping depends on what stage RKE is introduced into the process for shaping clay. There are thickness discontinuities in the vertical and horizontal plane and dented places on the vessel surface as a result of the thinning and shaping operations, whilst rotating most likely through a combination of Roux and Courtney's (1998) Method 1 and Method 2 (Ernst, in prep.). The finishing techniques consisted of smoothing the vessel surface. The firing conditions under which these ceramics were fired were either complete oxidization, or incomplete oxidation (but relatively well oxidised). There was no post-firing finishing. 


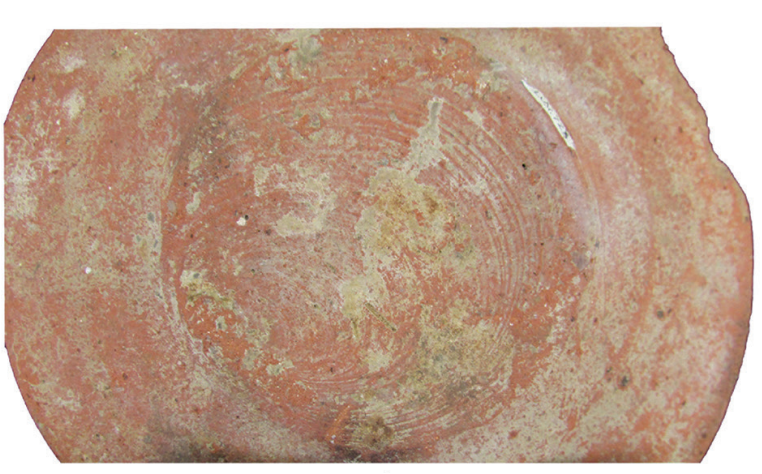

a)

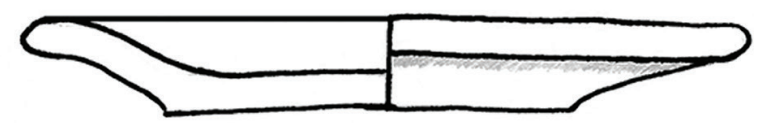

b) $10 \mathrm{~cm}$

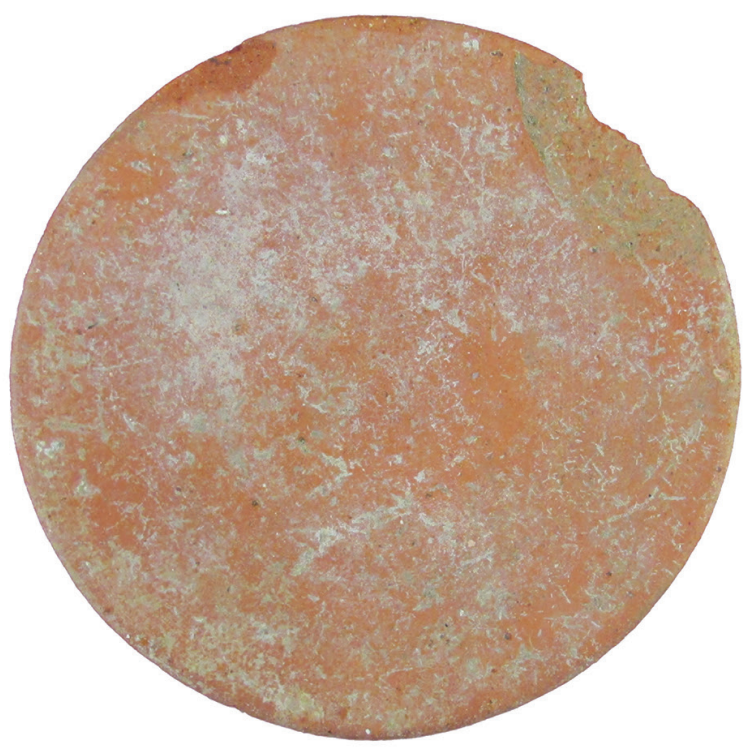

c)

Figure 2. Vessel shape and Macrotraces of Type 1 of the wheel-made ceramics from Concepción de la Vega and Cotuí: a) rilling and concentric striations on the base, b) top view of the plate, c) drawing of the vessel morphology.

All examples of this chaîne opératoire were the ones with a morphology representing plates. These are considered to be serving plates, most likely associated with serving wares for the Spaniards. None of the plates were decorated.

\subsection{Type 2}

The second category (Figure 3 ) is the largest one within the wheel-made assemblage. Generally seen, most of the clays selected for the manufacture of this group were of a very-fine to fine clay of a red or reddish-brown to greyish-brown paste.

Macrotraces consist of rilling over the entire vessel surface (Figure 3c). Very few base sherds were present, the few base sherds showing both concentric as well as arced striations at the bottom (Figure 3a). Like type 1, this group was also manufactured according to the wheel-coiling technique. Coil sizes range between 0.8 and $2.6 \mathrm{~cm}$ in diameter. Coil seams are rare, but when present they are not parallel to the rilling traces. The radial plane of this group shows coil joins with a flat join, but on the rare occasion S-shaped joins could be recognised in the thinner sherds (Figure 3b). Some drag marks are visible on the interior and the exterior walls of the vessels. These traces suggest that wheel coiling was done according to Roux and Courty's (1998) Method 3, meaning that the coils are built by discontinuous pressure, without the help of RKE. The joining of the coils, as well as the thinning and shaping, is done on the potter's wheel with RKE (Ernst, in prep.). The sherds are finished with fine rilling and some drag marks which show traces of rotational smoothing operations (Jeffra, 2011). The firing conditions under which these ceramics were fired were either complete oxidation, or incomplete oxidation (but relatively well oxidised). There was no post-firing finishing.

A small percentage (8\%) of sherds from this group showed evidence of component construction. This is when there are traces that indicate that a vessel is comprised of several parts formed separately and then joined together (fissures, overhangings, finger-pinching marks). In this case joining traces showcased a form of separate formation, which indicates the presence of two vessel body segments joined together. In these cases, there was the presence of a sharp change in wall angle, which would be difficult to create in one single potting action (Roux, 2019).

The majority of the vessels within this category are of an unrestricted jar with an almost straight wall, with orifice diameters ranging from 12 to $41 \mathrm{~cm}$. The second group entailed unrestricted jars with the largest diameter above the mid-height of the vessel and diameters up to $30 \mathrm{~cm}$ (Figure 3f). The profile of these larger jars (both restricted and unrestricted) suggests a possible association with sugar production, which was introduced to the Caribbean at Concepción de la Vega in 1503. Furthermore, this group also consists of pot lids with diameters between 8 and $12 \mathrm{~cm}$. There are two types of pot lids present: 1) the first has a flat base with upraised edges and one handle in the middle of the top of the lid; 2) the second shape has a hollow body that can be placed over a vessel's neck. This second pot lid shape was the shape that showed component construction. The last shape within this group consists of an open bowl.

About $50 \%$ of the sherds from this type are decorated. The dominant decorative technique is incised decoration; a comb-like tool is dragged over the surface of the vessel while still wet (Figure 3d). In this case, these comb-dragged patterns are often multi-banded with intersecting straight and wavy lines. The most common placement of the patterns is on, or just under, the rim, but they also appear on the inside of an open bowl, and along the entire surface of a pot lid. Some of the rims of the larger vessels do not only bear incisions, but are also decorated with a pattern created by finger pinching the rim whilst the clay is wet (Figure 3e). 

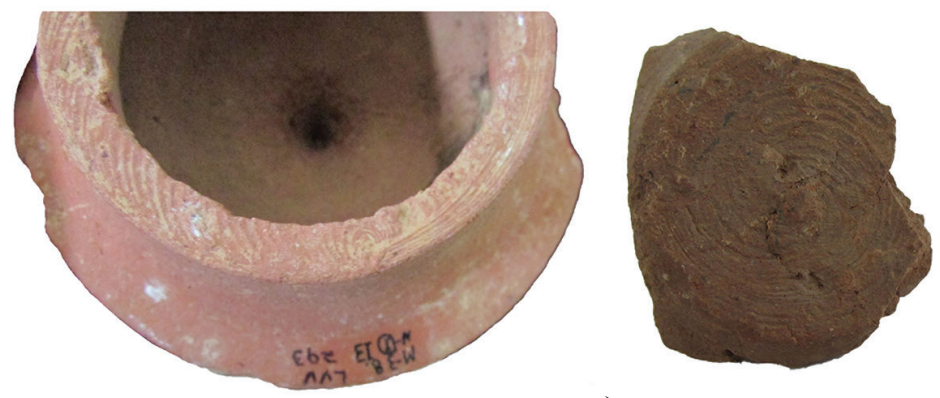

a)

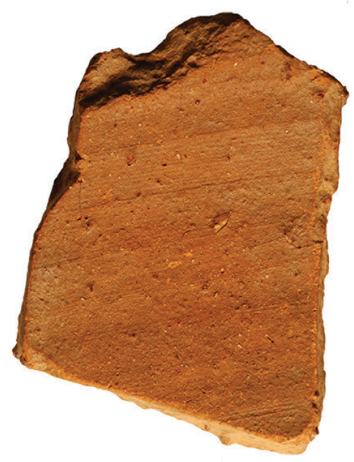

c)

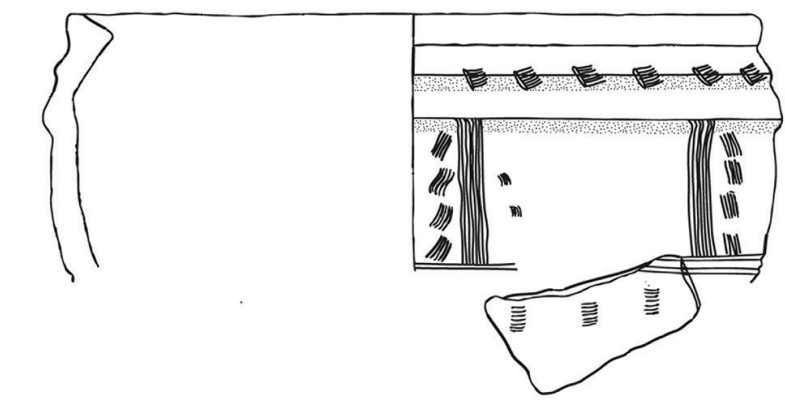

d)

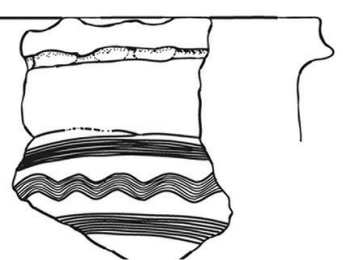

f)
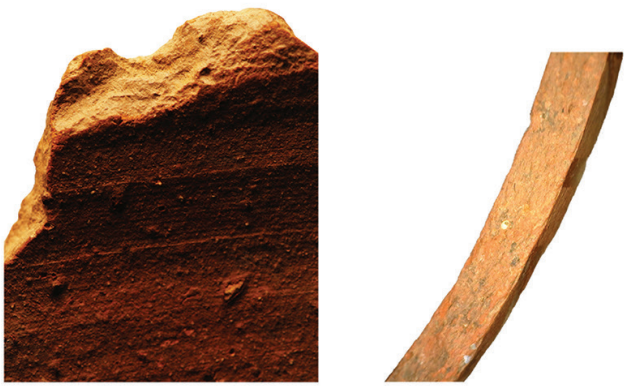

b)

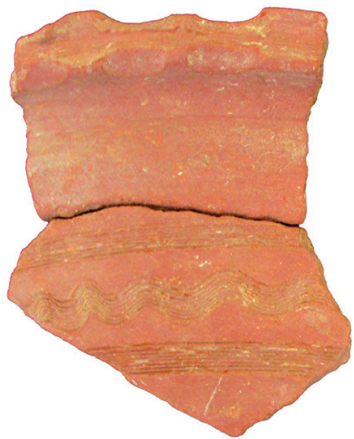

e)
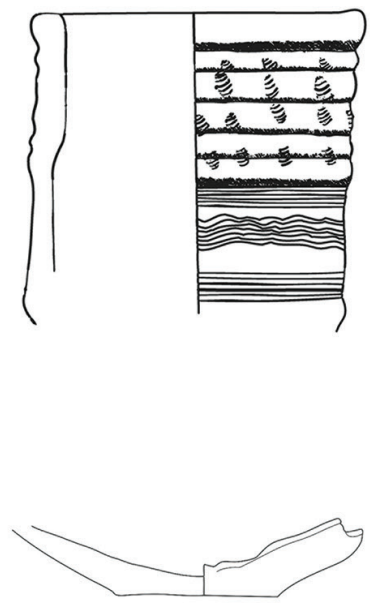

Figure 3. Vessel shape and macrotraces of type 2 of the wheel-made ceramics from Concepción de la Vega and Cotuí: a) concentric striations at the base, b) coil joining and traces of coils at the section, c) rilling, d) comb-dragged patterns, e) comb-dragged patterns in combination with finger pinching on the rim, f) vessel shapes.

\section{The introduction of the potter's wheel to colonial Hispaniola}

At this point it is impossible to identify exactly who manufactured the wheel-made ceramics at Concepción de la Vega and Cotuí. Taking the historical contexts of the colonies in mind, we know that ceramic traditions from the
Caribbean, the mainland of South America, Europe, and Africa could possibly have been introduced to the colony. In order to understand which traditions were introduced to the transculturation process, we can take a look at the chaînes opératoires of these ceramics in combination with their shapes and styles. The shape of the plates of Type 1 resembles the ones from Spain in form. However, they also differ much 
from the original Spanish serving plates. Spanish plates tend to be all-glazed: ranging from simple Melado glazes (i.e. simple lead-glazed wares) to intricate decorated majolicas such as Morisco wares, Columbia Plain, Yayal Blue on White, Isabela Polychrome, etc. (Deagan, 1987). None of the plates within this type had any decoration. Furthermore, Spanish plates tend to be slightly thinner than the plates presented here. The samples within Type 1 had an average thickness of $0.8 \mathrm{~mm}$ (against $0.5 \mathrm{~mm}$ for the Spanish plates). The indigenous ceramics of Hispaniola do not have similar plate shapes, the closest shape that can be considered somewhat similar are thin griddles. Thin griddles are also present within the assemblage of Concepción de la Vega and Cotuí. Like the plates they are coil built, but instead they are not shaped and finished on the wheel. Further, they do not have the diagnostic plate "foot" and they are completely flat instead of exhibiting a slight gradient like these plates do. Griddles in the Caribbean are generally used as cooking ware and often exhibit traces of use on the fire, although there are some examples that do not show traces of cooking (Ciofalo et al., 2019; Rodríguez Suarez and Pagán-Jiménez, 2008). None of the plates presented here exhibit fire traces. Coiling techniques are very common techniques within both indigenous Caribbean and African potting traditions pre1492. Meanwhile, the potter's wheel is a Spanish introduction to the chaîne opératoire of these ceramics (Ernst, in prep.).

For the second group, the shapes resemble typical Iberian forms that have descended from a long-standing Mediterranean ceramic tradition (Ernst and Hofman, 2019; Ernst and Weaver, in prep.). This accounts for all the shapes present within this group (i.e. the large unrestricted and restricted jars, the pot lids, and the open bowls). The large jars have most likely been introduced to the colony in connection with the sugar production that the Spanish started in Concepción de la Vega. But these vessels are not merely copy wares in which indigenous potters were forced to make Iberian shapes. The decorative attributes present seem to show the incorporation of Indigenous, African, and European techniques in the transculturation process very well. Combdragged and wavy line motifs are very common in Yoruba ceramics from West Africa since at least the $13^{\text {th }}$ century. And annular wavy-bands, both in singular and multiple registers, have a broader application in the ceramics associated with cultures throughout West Africa (Blier, 2015; Ernst and Hofman, 2019; Ernst and Weaver, in prep.; Manning, 2011).

Wheel-coiling uses the potter's wheel to facilitate the joining, thinning, or smoothing of the coiled roughout (Jeffra, 2011; Roux, 2019). It is proposed that the skills for wheelshaping is less difficult to learn then wheel-throwing, as they are an extension of hand-building techniques (Jeffra, 2011; Roux and Courty, 1998). This is because it does not imply a change from the accustomed practice, either in technique or skill. Wheel-shaping allows the potter to build vessels up in stages and can thus be adapted to a variety of manufacturing settings and equipment types. Wheel-shaping may allow the potter to make a vessel that resembles the wheel-throwing technique visually without spending too much time on learning this technology, which can be a potentially valuable cultural commodity.

Since the vessels are not wheel-thrown, a Spanish potter is less likely the maker; however, a Spanish person who knows the potting technique will likely have been involved in the learning process at some point in time.

\section{Final remarks}

The ceramic material presented in this article shows the first evidence of the use of the potter's wheel within the Caribbean colonies. Here I have shown that the introduction of the potter's wheel in the Americas was not a mere oneto-one transition from Spain to the Caribbean. The presence of Spanish vessel shapes, manufactured with Spanish, Indigenous, and African techniques, shows interesting steps within the transculturation process that occurred in Hispaniola after 1492.

The presence of Iberian vessel shapes within these wares could reflect the intention of the Spanish colonists to maintain their own known lifestyle within the colonies (RodriguezAlegria, 2005; Deagan and Cruxent, 2002). This can also be seen in the appearance of the vessels with a wheel finish. It might have meant that a Spanish-looking vessel was desired by the Spaniards (consumers) living in Concepción de la Vega and Cotuí. This is particularly shown within the wheel-made ceramics Type 1. Plates are here considered to be serving ware, used in the more visible spaces within the colony: hence the Spanish colonists probably had to utilise these ceramic items at some point in time. The presence of Type 1 with an Old-World shape and wheel-made appearance might have meant that Spanish-looking vessels were desired within these visible spaces of the colony. The local and African, traditional, roughout techniques suggests that these vessels were perhaps not made by Spanish potters, but by enslaved labourers within the colonial system. This could reveal some degree of cultural preservation within an enslaved situation in this early colonial setting (Ernst, 2016; Ernst and Hofman, 2019).

The presence of the comb-dragged lines within the wheel-made Type 2 ceramics shows the materialisation of the transculturation process quite well. The traces of the finishing on the potter's wheel as well as the presence of Iberian shapes show the influence of the Spaniards that were present in the colony. But at the same time, we see African decorative techniques as well as the use of Indigenous- and African-forming techniques. This offers us some insights into the agency of the enslaved peoples, living within the colonial systems of Concepción de la Vega and Cotuí. Although enslaved labourers within the colonial systems of Hispaniola are often seen to have lived marginal lives in the colonies, the transculturation in these pots shows us that within the less visible places in the colony people were very much able to maintain some of their traditions (Ernst, in prep.; Ernst and Hofman, 2019).

The ceramics presented in this paper have shown that both Indigenous and African enslaved peoples and Spanish 
colonists have influenced the ceramics in early colonial Hispaniola. The introduction of the potter's wheel is a Spanish introduction to the New World, while coiling techniques were prominent indigenous Caribbean and African techniques. The shapes of these vessels are likewise an Iberian influence. The vessels are made with local clays and the decoration technique has an African origin. This study has shown that wheel-made ceramics in early colonial Hispaniola have been made locally and that they are a result of a very interesting process of transculturation within intercultural interactions in the colonies. We should therefore not disregard these ceramics with traces of the potter's wheel as mere Spanish imports. Instead, it is important to recognise that these ceramics (when recognised as locally-made, transcultural ceramics) offer us great potential for studying colonial interactions and the agency of the enslaved. When studying the ceramic manufacture of these pots in relation to their historical background of colonialism and the realities of colonial life, we can start to understand ways in which consumer demand was countered with forms of cultural preservation - perhaps as a form of resistance against the colonial realities.

\section{Acknowledgements}

This paper presents data that is part of the author's forthcoming $\mathrm{PhD}$ dissertation: Early Colonial Mosaics, Transculturation within Ceramic Repertoires in the Spanish Colonial Caribbean 1495-1562, as part of the ERC NEXUS1492 project which received funding from the European Research Council under the European Union's Seventh Framework Program (gr. $n^{\circ} 319209$ ). I am grateful to the Faculty of Archaeology for their support during the last year of the $\mathrm{PhD}$. I wish to acknowledge my supervisors Corinne Hofman, Andzej Antcak, and Jorge Ulloa Hung for their guidance throughout my $\mathrm{PhD}$. This research has been enabled by the Museo del Hombre Dominicano, Parque Arqueológico Vega Vieja, and the Patrimonio Monumental of the Dominican Republic, by allowing me to conduct my research towards the materials of Cotui and Concepción de la Vega.

\section{References}

ANDERSON-CÓRDOVA, K.F., 2017. Surviving Spanish Conquest. Indian Fight, Flight, and Cultural Transformation in Hispaniola and Puerto Rico. Alabama: University of Alabama Press.

BLIER, S.P., 2015. Art and Risk in Ancient Yoruba: Ife history, power, and identity, c. 1300. Cambridge: Cambridge University Press.

BOGUES, A., 2002. Politics, nation and postcolony: Caribbean inflections. Small Axe, 6(1), 1-30.

CARD, J., 2007. The Ceramics of Colonial Ciudad Vieja, El Salvador: Culture Contact and Social Change in Mesoamerica. Tulane: Tulane University.

CIAFALO, A.J., SINELLI, P.T., and HOFMAN C.L., 2019. Late Precolonial Culinary Practices: Starch Analysis on Griddles from the Northern Caribbean. Journal of Archaeological Method and Theory,
26(4), 1632-1664.

COHEN, J., 1997. Preliminary Report on the 1996 Field Season at Concepción de la Vega. Project report submitted to the Dirección Nacional de Parques. Gainesville: Florida Museum of Natural History.

COOPER, F., 1994. Conflict and connection: Rethinking colonial African history. The American Historical Review, 99(5), 1516-1545.

COURTY, M.A., and ROUX, V., 1995. Identification of Wheel Throwing on the Basis of Ceramic Surface Features and Microfabrics. Journal of Archaeological Science, 22, 17-50.

DEAGAN, K.A., 1987. Artifacts of the Spanish Colonies of Florida and the Caribbean, 1500-1800, vol. 1: Ceramics, Glassware, and Beads. Washington, D.C.: Smithsonian Institution Press.

DEAGAN, K.A., 1988. The Archaeology of the Spanish Contact Period in the Caribbean. Journal of World Prehistory, 2(2), 187-233.

DEAGAN, K.A., 1998. Transculturation and Spanish American Ethnogenesis: The Archaeological Legacy of the Quincentenary. In: J.G. Cusick, ed. Studies in Culture Contact: Interaction, Culture Change, and Archaeology, Occasional Paper Vol. 25. Carbondale: Center for Archaeological Investigations, Southern Illinois University, pp. 23-43.

DEAGAN, K.A., 1999. Cultural and Historical Resources at the Parques Nacionales Concepción de la Vega and La Isabela: Final project report submitted to the Dirección Nacional de Parques. Gainesville: Florida Museum of Natural History - University of Florida.

DEAGAN, K.A., 2004. Reconsidering Taino Social Dynamics after Spanish Conquest: Gender and Class in Culture Contact Studies. American Antiquity, 69(4), 597-626.

DEAGAN, K.A., and CRUXENT, J.M., 2002. Archaeology at La Isabela: America's First European Town. New Haven: Yale University Press.

DEIVE, C.E., 1980. La esclavitud del negro en Santo Domingo (14921844). Santo Domingo: Museo del Hombre Dominicano.

DUISTERMAAT, K., 2016. The Organization of Pottery Production: Toward a Relational Approach. In: A. Hunt, ed. The Oxford Handbook of Archaeological Ceramic Analysis. Oxford: Oxford University Press, pp. 114-147.

EDWARDS, A., 2017. Resistance and Reforms: The Role of Subaltern Agency in Colonial State Development. Political Power and Social Theory, 33, 175-201.

ERNST, M., in prep. Early Colonial Mosaics, Transculturation within Ceramic Repertoires in the Spanish Colonial Caribbean 1495-1562. Unpublished thesis (PhD), Leiden University.

ERNST, M., and HOFMAN, C.L., 2019. Breaking and Making Identities: Transformations of Ceramic Repertoires in Early Colonial Hispaniola. In: C.L. Hofman, and F.W.M. Keehnen, eds. Material Encounters and Indigenous Transformations in the Early Colonial Americas: Archaeological Case Studies. The Early Americas: History and Culture, 9, Leiden: Brill, pp. 124-145.

ERNST, M., and WEAVER, B.J.M., in prep. Towards a comparative analysis of African-influenced ceramic motifs in the Spanish Americas: Hispaniola and Peru (working title).

GARCÍA ARÉVALO, M., 1978. La arqueología indo-hispana en Santo Domingo. In: E. Wagner, and A. Zucchi, eds. Unidades y variedades: Ensayos en homenaje a José M. Cruxent. Caracas: Centro de Estudios Avanzados, pp. 77-127.

GOSDEN, C., 2006. Material culture and long-term change. In C. Tilley, W. Keane, S. Küchler, M. Rowlands, and P. Spyer, eds. Handbook of material culture. London: Sage Publications, pp. 24-42.

GOSSELAIN, O.G., 1998. Social and Technical Identity in a Clay Crystal Ball. In: M.T. Stark, ed. The Archaeology of Social Boundaries. Washington DC: Smithsonian Institution Press, pp. 78-106.

GOSSELAIN, O.G., 1999. In Pots We Trust. Journal of Material Culture, 4, 205-230.

GOSSELAIN, O.G., 2000. Materializing identities: an African perspective. Journal of Archaeological Method and Theory, 7(3), 187-217.

GOSSELAIN, O.G., 2011. Technology. In: T. Insoll, eds. The Oxford Handbook of the Archaeology of Ritual and Religion. Oxford: Oxford University Press.

GUERRO, J., 2005. Cotuí: Villa, Carnaval, Cofradía y Palos. Un estudio etnohistórico. Santo Domingo: Universidad Autónoma de Santo Domingo.

HOFMAN, C.L., 1993. In Search of the Native Population of PreColumbian Saba (400-1450 A.D.). Part One: Pottery Styles and their 
Interpretations. Unpublished thesis (PhD), Leiden University.

HOFMAN, C.L., and KEEHNEN, F.W.M., 2019. Material Encounters and Indigenous Transformations in the Early Colonial Americas: Archaeological Case Studies. The Early Americas: History and Culture, 9, Leiden: Brill.

HOFMAN, C.L., ULLOA HUNG, J., HERRERA MALATESTA, E., JEAN, J.S., and HOOGLAND, M.L.P., 2018. Indigenous Caribbean Perspectives: Archaeologies and legacies of the first colonized region in the New World. Antiquity, 92(361), 200-216.

HOFMAN, C.L., ULLOA HUNG, J., DAVIES, G.R., and BRANDES, U., forthcoming. Nexus 1492: New World Encounters in a Globalizing World. A Synthesis. Leiden: Brill.

JAMES, C.L.R., 1963. The black Jacobins: Toussaint L'Ouverture and the San Domingo revolution. New York: Vintage Books.

JEFFRA, C.D., 2011. The Archaeological Study of Innovation: An Experimental Approach to the Pottery Wheel in Bronze Age Crete and Cyprus. Unpublished thesis (PhD), University of Amsterdam.

KULSTAD, P., 2019. Hispaniola - hell or home? : decolonizing grand narratives about intercultural interactions at Concepción de la Vega (1494-1564). Leiden: Sidestone Press.

LAS CASAS, B. de, [1527] 1974. Historia de las Indias. vol I, II and III Santo Domingo: Editora Corripio, Sociedad Dominicana de Bibliófilos.

LEMONNIER, P., 1992. Elements for an Anthropology of Technology. Ann arbor, MI: The University of Michigan, The Museum of Anthropology (Anthropological Papers, 88).

LEMONNIER, P., 2012. Mundane objects: Materiality and non-verbal communication. Walnut Creek, CA: Left Coast Press.

LEROI-GOURHAN, A., 1964. La gueste et la parole. Paris: French ministry of culture. Massachusetts: Massachusetts Institute of Technology.

LIVINGSTONE SMITH, A., 2000. Processing Clay for Pottery in Northern Cameroon: Social and Technical Requirements. Archaeometry, 42, $21-42$.

MCEWAN, B.G., 1995. Spanish Precedents and Domestic Life at Puerto Real: The Archaeology of Two Spanish Homesitesd. In: K.A. Deagan, ed. Puerto Real: The Archaeology of a Sixteenth-Century Spanish Town in Hispaniola. Gainesville: University Press of Florida, pp. 197-229.

MANÉM, S., 2008. Etude des fondements technologiques de la culture des Duffaits (âge du Bronze moyen). Unpublished thesis (PhD), University of Paris-Nanterre.

MANNING, K., 2011. Potter communities and technological tradition in the Lower Telemsi Valley, Mali. Azania Archaeological Research in Africa, 46(1), 70-87

OLSEN BOGEART, H.G., ULLOA HUNG, J., AVILA, V., and COSTE F., 2011a. Pueblo Viejo Dominicana Corporation, Projecto Pueblo Viejo. Sitio Arqueológico No. 11 Investigación Estructuras Coloniales. Unpublished excavation report, Faculty of Archaeology, Leiden University.

OLSEN BOGEART, H.G., ULlOA HUNG, J., AVILA, V., and COSTE, F., 2011b. Pueblo Viejo Dominicana Corporation, Projecto Pueblo Viejo, Sitio Arqueológico No. 11 2da fase de investigación. Unpublished excavation report, Faculty of Archaeology, Leiden University.

ORTEGA, E., 1980. Introduccion a la Loza Comun o Laferareria en el Periodo Colonial de Santo Domingo. Santo Domingo: Taller.

ORTEGA, E., and FONDEUR, C., 1978a. Arqueología de los monumentos históricos de Santo Domingo. San Pedro de Macorís: Universidad Central del Este.

ORTEGA, E., and FONDEUR, C., 1978b. Estudio de la Cerámica del Periodo Indo- Hispánico de la Antigua Concepción de La Vega. Santo Domingo: Taller.

ORTIZ, F., [1940] 1995. Cuban Counterpoint: Tobacco and Sugar. Translated by Harriet de Onís. Durham: Duke University Press. Originally published in Spanish in 1940, Havana: Editorial de Ciencias Sociales.

OVIEDO, F.G., 1851 [1535]. Historia General y Natural de las Indias, Islas y Tierra-Firme del Mar Océano, vol. 1. Edited by J.A. de los Ríos. Madrid: La Real Academia de la Historia.

PALMIÉ, S., 2011. The Caribbean: A History of the Region and Its Peoples. Chicago: University of Chicago Press.

PANÉ, F.R., [1571] 1999. An Account of the Antiquities of the Indians. Chronicles of the New World Encounter. Translated by S.C. Griswold 1999 facsimile edition with an introductory study, notes and appendices by J.J. Arrom. Durham and London: Duke University Press.
RICE, P.M., 1984. Change and Conservatism in Pottery-Producing Systems. In: S. van der Leeuw, ed. The Many Dimensions of Pottery: Ceramics in Archaeology and Anthropology. Amsterdam: Van Giffen Instituut voor Pre- en Protohistorie, pp. 231-293.

RINCÓN, F., 2004. La Mejorada Villa del Cotuy. Cotuí: Impresora Edison. RIVERA-PAGÁN, L.N., 2003. Freedom and servitude: indigenous slavery and the Spanish Conquest of the Caribbean. In: J. Sued Badillo, ed. General History of the Caribbean 1. Paris: UNESCO publishing.

RODRÍGUEZ-ALEGRÍA, E., 2005. Eating Like an Indian: Negotiating Social Relations in the Spanish Colonies. Current Anthropology, 46(4), 551-573.

RODRÍGUEZ SUÁREZ, R., and PAGÁN-JIMÉNEZ, J.R., 2008. The Burén in precolonial Cuban archaeology: new information regarding the use of plants and ceramic griddles during the Late Ceramic Age of Eastern Cuba gathered through starch analysis. In: C.L. Hofman, M.L.P. Hoogland, and A.L. van Gijn, eds. Crossing the borders, new methods and techniques in the study of archaeological materials from the Caribbean. Tuscaloosa: The University of Alabama Press, pp. 159-169.

ROUSE, I., 1992. The Tainos: Rise and Decline of the People who Greeted Columbus. New Haven: Yale University Press.

ROUX, V., 2016a. Ceramic Manufacture: The Chaîne Opératoire Approach. In: A.M.W. HUNT, ed. The Oxford Handbook of Archaeological Ceramic Analysis. Oxford: Oxford University Press, pp. 101-113.

ROUX, V., 2016b. Des céramiques et des hommes: Décoder les assemblages archéologiques. Paris: Presses Universitaires de Paris Ouest.

ROUX, V., 2019. Ceramics and Society. A Technological Approach to Archaeological Assemblages. Cham: Springer.

ROUX, V., and COURTY, M.A., 1998. Identification of Wheel-Fashioning Methods: Technological Analysis of $4^{\text {th }}-3^{\text {rd }}$ Millennium BC Oriental Ceramics. Journal of Archaeological Science, 25, 747-763.

ROUX, V., and COURTY, M.A., 2013. Introduction to Discontinuities and Continuities: Theories, Methods and Proxies for a Historical and Sociological Approach to Evolution of Past Societies. Journal of Archaeological Method and Theory, 20(2). DOI: 10.1007/s10816-0139170-y

SAUER, C.O., 1966. The Early Spanish Main. Berkeley and Los Angeles: University of California Press.

SHEPARD, A.O., 1976. Ceramics for the archaeologist. Washington D.C.: Carnegie Institution of Washington.

SHEPHARD, H., 1997. A Report: The Fort at Concepción de la Vega, Dominican Republic and Standards, Interpretation and Conservation. Consultant report, submitted to the Dirección Nacional de Parques, Santo Domingo, and U.S.A.I.D. Gainesville: Florida Museum of Natural History.

SKIBO, J.M., and SHIFFER, M.B., 2008. People and Things. A Behavioural Approach to Material Culture. New York: Springer.

SPIELMAN, K.A., MOBLEY-TANKA, J.L., and POTTER, J.M., 2006. Style and Resistance in the Seventeenth Century Salinas Province. American Antiquity, 71(4), 621-647.

SUED BADILlO, J., 2001. El Dorado Borincano: La Economía de la Conquista 1510-1550. San Juan: Ediciones Puerto.

TING, C., ULlOA HUNG, J., HOFMAN C.L., and DEGRYSE, P., 2018. Indigenous Technologies and the Production of Early Colonial ceramics in Dominican Republic. Journal of Archaeological Science Reports, 17, 47-57.

ULLOA HUNG, J., VALCÁRCEL ROJAS, R., ANTCZAK, A., ERNST, M., HOOGLAND, M.L.P., and HOFMAN, C.L., 2021. Social Networks and Colonial Adaptation in the Caribbean. In: L.M. Panich, S.L. Gonzales, eds. The Routledge Handbook of the Archaeology of Indigenous-Colonial Interaction in the Americas, London: Rootledge. DOI: $10.4324 / 9780429274251$

VAN DER LEEUW, S.E., 1993. Giving the potter a choice. Conceptual aspects of pottery techniques. In: P. Lemonnier, ed. Technological choices: transformation in material cultures since the Neolithic. London: Routledge, pp. 23-288.

VALCÁRCEL ROJAS, R., SAMSON, A.V.M., and HOOGLAND, M.L.P., 2013. Indo-Hispanic Dynamics: From Contact to Colonial Interaction in the Greater Antilles. International Journal of Historical Archaeology, $17(1), 18-39$.

VALCÁRCEL ROJAS, R., LAFFOON, J.E., WESTON, D.A., HOOGLAND, M.L.P., and HOFMAN, C.L. 2019. Slavery of Indigenous 
People in the Caribbean: An Archaeological Perspective. International Journal of Historical Archaeology, 24, 517-545.

VIVENS VIVES, J., 1969. An Economic History of Spain. Princeton: Princeton University Press.

WALLAERT, H., 2008. "The Way of the Potter's Mother. Apprenticeship Strategies Among Dii Potters from Cameroon, West Africa. In:
M.T. Stark, B.J. Browser, and L. Horne, eds. Cultural Transmission and Material Culture, Breaking Down Boundaries. Tucson: The University of Arizona Press, pp. 178-198.

WILSON, S.M., 1990. Hispaniola: Caribbean Chiefdoms in the Age of Columbus. Tuscaloosa: University of Alabama Press. 